\title{
INFLUENCE OF SEISMIC LOADING ON AXIAL LOAD VARIATION IN REINFORCED CONCRETE COLUMNS
}

Hugo Rodrigues

Scientific paper/ Znanstveni rad

(Received: 7 May 2018; accepted: 8 June 2018)

RISCO, School of Technology and Management, Polytechnic Institute of Leiria, Senior Lecturer

Corresponding author: hugo.f.rodrigues@ipleiria.pt

André Furtado

CONSTRUCT-LESE, Faculty of Engineering (FEUP), University of Porto, student

António Arêde

CONSTRUCT-LESE, Faculty of Engineering (FEUP), University of Porto, Associated Professor

Humberto Varum

CONSTRUCT-LESE, Faculty of Engineering (FEUP), University of Porto, Full Professor

\begin{abstract}
Experimental tests demonstrated the importance of the axial load variation in the seismic response of $\mathrm{RC}$ columns, namely, through the reduction in the strength capacity, reduced deformation capacity, and reduced energy dissipation capacity. Thus, this manuscript aims to study the axial load variability of RC columns, according to the plan and height disposition, and assess the relationship between the corresponding column flexure capacity and its influence on the global response of the structure. Hence, three RC structures were modeled using the software SeismoStruct and subjected to non-linear static pushover and dynamic analyses. According to the results, which are assessed in terms of capacity curves, axial load variation, and story/global shear capacity of each model, it can be concluded that the axial load variation is higher in the bottom storys and decreases with the story height of the structure. As observed, the corner columns reached a higher axial load variation than the façade and central columns.
\end{abstract}

Keywords: RC columns; Variable axial load; Biaxial bending; Numerical modeling; SeismoStruct

\section{UTJECAJ POTRESNOG DJELOVANJA NA PROMJENU OSNOG OPTEREĆENJA U ARMIRANOBETONSKIM STUPOVIMA}

\section{Sažetak:}

Eksperimentalna ispitivanja pokazala su važnost utjecaja promjene osnog opterećenja u seizmičkom odgovoru AB stupova, kroz smanjenje kapaciteta nosivosti, smanjenje kapaciteta deformacija i smanjenje disipacije energije. Sukladno tome, u ovome je radu istražena promjena osnog opterećenja stupova, ovisno o položaju u tlorisu i po visini konstrukcije. Predstavljena je i veza između pripadajućeg savojnog kapaciteta stupa te utjecaja na globalni odziv konstrukcije. Stoga su modelirane tri AB konstrukcije, analizirane pomoću nelinearne statičke (pushover) i dinamičke analize u Seismostruct programu. Na osnovi rezultata, koji su prikazani krivuljama kapaciteta nosivosti, promjenom osnog opterećenja i katnim/globalnim posmičnim kapacitetom svakog modela, može se zaključiti da promjena osnog opterećenja ima najveći utjecaj u nižim katovima te da opada $s$ povećanjem visine konstrukcije. Kao što je prikazano, rubni stupovi konstrukcije više su izloženi promjeni osnog opterećenja u odnosu na fasadne i centralne stupove.

Ključne riječi: armiranobetonski stupovi; promjenjivo osno opterećenje; dvoosno savijanje; numeričko modeliranje; SeismoStruct 


\section{INTRODUCTION}

In recent years, a significant increase in losses related to damages in existing structures from seismic events has been observed. Analyses performed on several real case studies show that part of these damages can be related with the structural behavior that occasionally leads to the collapse of buildings [1].

Thus, the losses were verified to be due to seismic events, depending on the earthquake intensity, construction density, and population density of the area where it occurred [2-4]. These problems emphasize the need for further knowledge gain in the field of seismic engineering, to increase the understanding of the models that simulate the behavior of the structures such that their response can be predicted to improve the design and reduce future losses. The behavior of reinforced concrete $(\mathrm{RC})$ structures has led to several numerical and experimental studies with the objective of increasing the existing knowledge in this domain [5-10]. The axial load variation during an earthquake can affect the ultimate strength and deformation capacity, as well as the RC element hysteretic properties [11]. Such variations can occur due to the vertical component of the seismic action, or the overturning moments, especially in the exterior columns. Several researchers $[12,13]$ have stated that the axial stress variations, combined with the cyclic horizontal action, significantly affects the inelastic response of the columns. Rodrigues et al. [14] reported that due to the difficulties in performing the experimental tests, the number of columns tested under bidirectional loads and variable axial stress available in the literature is very small. This lack of experimental results does not allow researchers to draw strong conclusions about the effects and interactions between the biaxial flexural behavior and axial load variation. Li et al [15] and Low and Moehle [16] observed the effects of axial stress variation on uniaxial and biaxial bending. By analyzing the experimental results, they found that the variation in the axial load, along with horizontal loads, led to an increase in stiffness and maximum strength, and that the strength degradation was higher for high axial load values and decreased when the values of axial forces decreased [17, 18]. More recently, Rodrigues et al. [11, 19] performed a test campaign to investigate one of the gaps identified in the previous studies and proceeded to evaluate the behavior of six RC columns subjected to biaxial horizontal loading under variable axial load. Thus, the effect of axial load variation was evaluated throughout the experimental tests, in terms of damage evolution, global inelastic behavior, stiffness degradation, strength degradation, and energy dissipation. As a result of this experimental campaign, the variation in the axial load combined with the horizontal biaxial bending was found to have significant effects on the nonlinear behavior and the capacity of the columns. Further, the initial stiffness was found not significantly affected by the horizontal biaxial loading with axial load variation. However, these loading characteristics reduce the maximum strength of the columns and the corresponding yielding plateau, leading to faster strength degradation, and reduced ultimate ductility. It has also been observed that each damage state for the variable axial loading conditions occurs for a lower drift demand when compared to the corresponding damage states for the constant axial load. The combination of biaxial loading with variable axial stress leads to a reduction of approximately $60 \%$ of the drift at which each damage state occurs. The stiffness degradation is significantly affected by the variable axial load for different loading paths, but it presents a smooth behavior when compared with the tests performed for a constant axial load. Because the research focused on the effects of variable axial load on the hysteretic behavior of RC columns under horizontal biaxial loading, the authors concluded that significant variations in the observed response in terms of column strength, anticipation of damage, stiffness, strength degradation, and dissipated energy suggest that the effects of axial stress combined with the biaxial bending stress of the columns are important aspects, especially in the exterior corner columns, which should not be neglected.

Xu et al. [20] tested five full-scale rectangular RC columns under uniaxial horizontal loadings combined with variable axial load ratios. From the tests, the authors concluded that larger variations of axial load caused a higher decrease in the columns' lateral strength, ductility factor, and secant stiffness.

The primary objective of the present work is to analyze the variability of the axial load in the columns, as a function of its location in plant and height, aiming to investigate the possible relation with the biaxial bending and its influence on the response. 


\section{CASE STUDIES}

\subsection{ELSA frame}

The first structure under study consists of a full-scale RC frame structure, four story high and designed in accordance with EC2 and EC8. It is a high-ductility structure (according to the EC8 classification whose general layout is shown in Figure 1). The structure was subjected to a pseudodynamic test in Ispra (Italy), where the behavior of real structures designed with high seismic demands was assessed. More details regarding the experimental campaign can be found in [21,22]. The structure is symmetric with two identical frames and a stronger central one. In the orthogonal direction, it is asymmetric owing to the different span lengths, leading to a slight irregularity, which was introduced for a more realistic building and for possible tests in this direction. The external columns have cross sections of $40 \mathrm{~cm} \times 40 \mathrm{~cm}$, while those of the central one are $45 \mathrm{~cm} \times 45 \mathrm{~cm}$. All the beams are $30 \mathrm{~cm}$ wide and $45 \mathrm{~cm}$ high, and the solid slabs are $15 \mathrm{~cm}$.

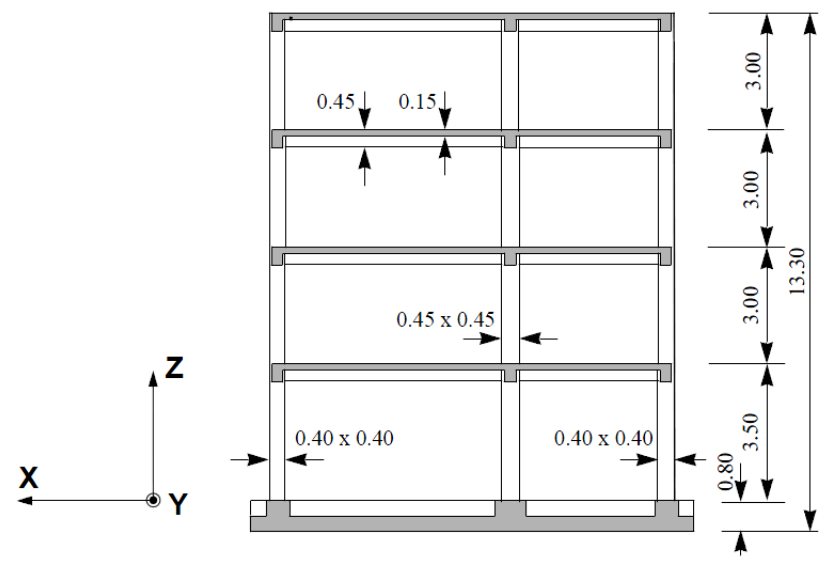

a)

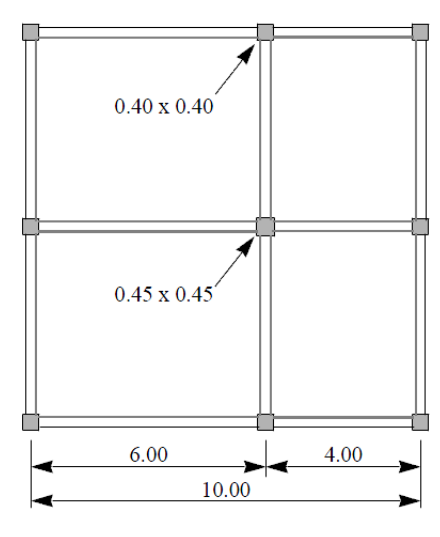

b)

Figure 1 Elsa frame structure: general layout

The structure was cast in place with concrete $\mathrm{C} 25 / 30$ as specified in the EC2 and B500S steel reinforcement class. The structural design was performed for typical loads (additional dead load of $2 \mathrm{kN} / \mathrm{m}^{2}$ ) and high seismicity, assuming a peak ground acceleration of $0.3 \mathrm{~g}$, soil type $\mathrm{B}$, and importance factor of 1 . Because the irregularity requirements are fulfilled, both in the plan and elevation, the design was performed for high regularity and no reduction in the behavior factor. More details regarding the structure design can be found in [21, 22]. The concrete and steel reinforcement material properties are summarized in Table 1.

Table 1 Elsa frame: material properties

\begin{tabular}{ccccccccc}
\hline & & Concrete & & \multicolumn{4}{c}{ Steel reinforcement } \\
$E_{c m}$ & $f_{c k}$ & $f_{c t m}$ & $\varepsilon_{c 0}$ & $r_{c}\left(k N / m^{3}\right)$ & $E_{c m}$ & $f_{s y}$ & $E_{s h}$ & $\varepsilon_{s m}$ \\
$(\mathrm{GPa})$ & $(\mathrm{MPa})$ & $(\mathrm{MPa})$ & $(\%)$ & $(\mathrm{MPa})$ & $(\mathrm{MPa})$ & $(\%)$ \\
31 & 25 & 2.6 & 2.0 & 25 & 200 & 569.25 & 0.95 & 10 \\
\hline
\end{tabular}

\subsection{PT4 and PT6}

The second and third structures under study were four- and six-story structures (named PT4 and PT6, respectively). The buildings were designed according to the actual structural design code in Portugal [23]. The two structures have the same plan dimensions of $20 \mathrm{~m} \times 15 \mathrm{~m}$ with a story height of $3 \mathrm{~m}$ (Figure 2). 


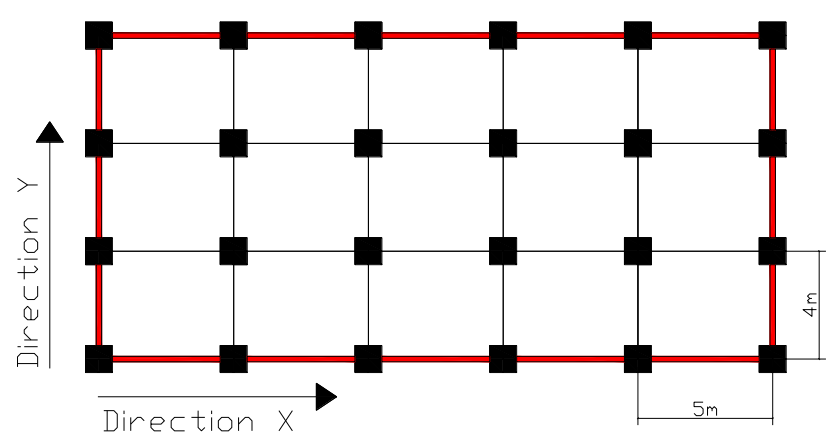

a)

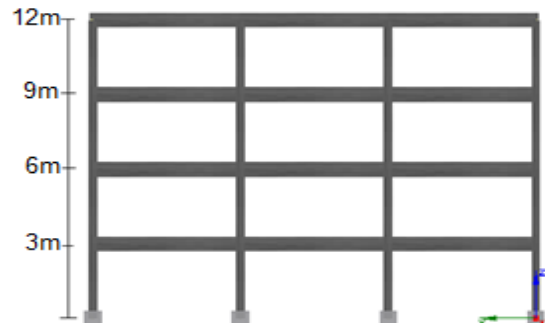

b)

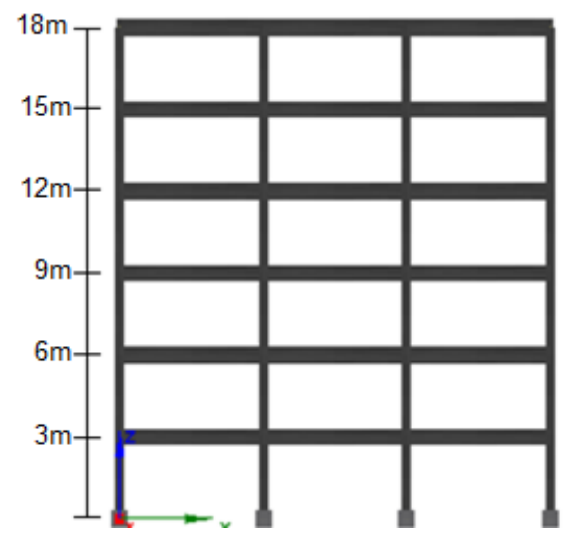

d)

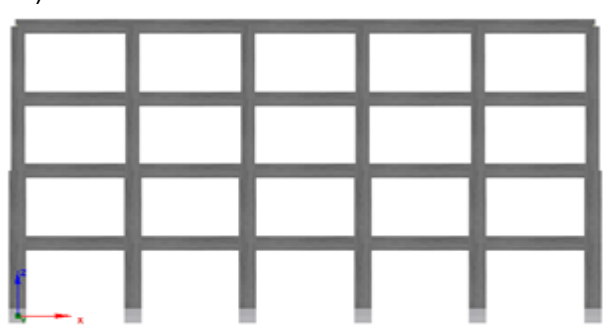

c)

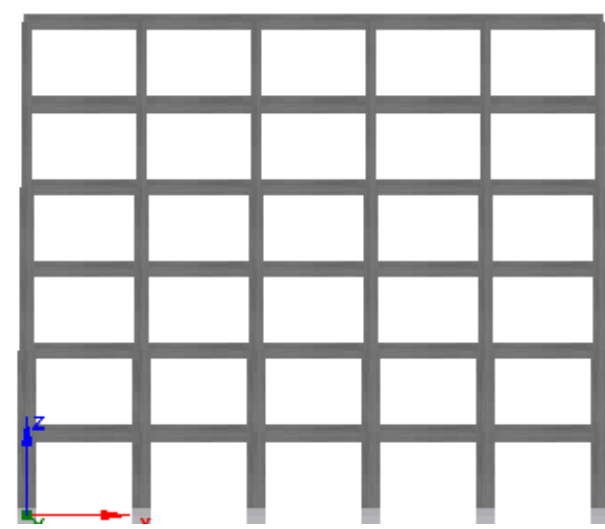

e)

Figure 2 PT4 and PT6: general layout a) plan dimensions; b) PT4 longitudinal frame type; c) PT4 transverse frame type; d) PT6 longitudinal frame type and e) PT6 transverse frame type

The cross-section dimensions of both structures are summarized in and the reinforcement details can be found in [23]. The design of the structures was performed considering the structural elements' self-weight, slab self-weight (thickness of $0.15 \mathrm{~m}$ ), and other dead loads (of $2.45 \mathrm{kN} / \mathrm{m}^{2}$ ). The live loads assumed were 0.396 $\mathrm{kN} / \mathrm{m}^{2}$. As mentioned, it was assumed that the structures were built in a medium-high seismic activity region, which according to the actual Portuguese structural design standard RSA [24] is a type-A region of type-II soil.

The material properties used for the structural design of both buildings were of concrete class C25/30, according to Eurocode 2 [25], with the concrete compressive strength of $25 \mathrm{MPa}$, elasticity modulus of $25 \mathrm{GPa}$, tensile strength of $3.9 \mathrm{MPa}$, strain at peak stress of $0.36 \%$, and a self-weight of $25 \mathrm{kN} / \mathrm{m}^{3}$. The reinforcement steel was A400, with a yield strength equal to $400 \mathrm{MPa}$, elasticity modulus of $210 \mathrm{MPa}$, yielding strain of $1.9 \%$, and a maximum peak strain of $100 \%$.

Table 2 PT4 and PT6: Cross-section dimensions

\begin{tabular}{|c|c|c|c|c|}
\hline \multirow[t]{2}{*}{ Structure } & \multicolumn{3}{|c|}{$\begin{array}{l}\text { Columns }(\mathrm{h} \times \mathrm{b}) \\
(\mathrm{mm})\end{array}$} & \multirow[t]{2}{*}{$\begin{array}{c}\text { Beams }(\mathrm{h} \times \mathrm{b}) \\
(\mathrm{mm})\end{array}$} \\
\hline & 0-2 & $2-4$ & $4-6$ & \\
\hline PT4 & $400 \times 300$ & $300 \times 300$ & $\mathrm{~N} / \mathrm{A}$ & $500 \times 200$ \\
\hline PT6 & $500 \times 300$ & $400 \times 300$ & $400 \times 300$ & $500 \times 200$ \\
\hline
\end{tabular}

Rodrigues, $\mathrm{H}$, Furtado, A, Arêde, A, Varum, $\mathrm{H}$ 


\subsection{Numerical modeling strategies}

The numerical models were built in the software SeismoStruct [26] based on the material models and elements available in the software library. Three-dimensional (3D) models were built for the three structures under study. The SeismoStruct provide different modeling approaches to simulate the RC elements' seismic behavior: elements with distributed inelasticity (force- or displacement-based formulations) or elements with lumped plasticity (with fixed plastic-hinge length). For the current study, fiber discretization was adopted to simulate the behavior at the section level, where each fiber is associated with a uniaxial stress-strain law. The sectional moment-curvature state of the beam and column elements is subsequently obtained through the integration of the nonlinear uniaxial stress-strain response of the individual fibers into which the section has been subdivided.

The RC frame structure was modeled considering the beam with hinges and the plastic hinge length assumed was considered as half of their higher cross-section dimensions. This decision was based on the reports provided by Priestley and Park [27], Paulay and Priestley [28] and by other authors who have concluded from experimental evidence that the plastic hinge length is not strongly affected by two-dimensional loading [29]. The modeling assumptions adopted for the beams and columns were based on the conclusions of the work developed by Rodrigues et al. [30], in which they studied the biaxial flexural behavior of RC columns. For the concrete modeling, the uniaxial material model based on the Mander et al. [31] and Madas [32] uniaxial models was adopted. The confined and unconfined concrete follows the cyclic rules, included in this model, were proposed by Martinez-Rueda and Elnashai [33]. The confinement effects provided by the transverse reinforcement are considered through the rules proposed by Mander et al. [31], whereby a constant confining pressure is assumed throughout the entire stress-strain range, indicated by the increase in the peak value of the compression strength and the stiffness of the unloading branch. The confinement factor for each cross section was obtained from the Mander et al. [31] proposal. For the steel reinforcement simulation, the uniaxial model proposed by Menegotto and Pinto [34] was adopted, combined with the isotropic hardening rules proposed by Filippou et al. [35]. This model considers the Bauschinger effect, which is relevant for the representation of the columns' stiffness degradation under cyclic loading.

The input material properties assumed for the Elsa frame structure are in agreement with the material properties obtained by the authors and described in 2.1 , namely a compressive strength of $25 \mathrm{MPa}$, a concrete tensile strength of $2.6 \mathrm{MPa}$, a concrete peak strength strain of $2.0 \%$, and an elasticity modulus of $31 \mathrm{GPa}$. The input properties assumed for the steel reinforcement were a yield strength of $570 \mathrm{MPa}$, an elasticity modulus of 194.7 GPa, a strain-hardening ratio of $2.71 \%$, a transition curve initial shape (Ro) of 20 , and transition curve shape parameters $\mathrm{a} 1$ and $\mathrm{a} 2$ of 18.5 and 0.15 , respectively. Finally, the isotropic hardening parameters a3 and a4 were assumed the values of 0.025 and 2 , respectively.

The PT4 and PT6 numerical models were built with the same material properties, which are in agreement with the properties obtained in the material tests and summarized in Table 3. The input material properties assumed for the reinforcement steel are also in agreement with the properties obtained in the material tests. For the other parameters, the default values are summarized in Table 4.

Table 3 PT4 and PT6 input material properties: Concrete

\begin{tabular}{cccc}
\hline $\begin{array}{c}\text { Compressive } \\
\text { strength } \\
\text { fc }(\mathrm{MPa})\end{array}$ & $\begin{array}{c}\text { Tensile strength } \\
\text { ft. (MPa) }\end{array}$ & $\begin{array}{c}\text { Strain at peak } \\
\text { strength } \\
\varepsilon \mathrm{C}(\%)\end{array}$ & $\begin{array}{c}\text { Confinement } \\
\text { factor }^{*}\end{array}$ \\
25.00 & 3.94 & 0.36 & 1.11 \\
\hline
\end{tabular}

* the confinement factor was obtained from the Mander et al. [31] proposal

Table 4 PT4 and PT6: input material properties for reinforcement steel

\begin{tabular}{|c|c|c|c|c|c|c|c|}
\hline $\begin{array}{l}\text { Elasticity } \\
\text { modulus }\end{array}$ & $\begin{array}{l}\text { Yield } \\
\text { strength }\end{array}$ & $\begin{array}{l}\text { Strain hardening } \\
\text { parameter }\end{array}$ & $\begin{array}{c}\text { Transition curve initial } \\
\text { shape }\end{array}$ & \multicolumn{2}{|c|}{$\begin{array}{c}\text { Transition curve } \\
\text { shape }\end{array}$} & \multicolumn{2}{|c|}{$\begin{array}{l}\text { Isotropic } \\
\text { hardening }\end{array}$} \\
\hline Es (GPa) & fy (MPa) & $r(\% 0)$ & Ro & a1 & a2 & a3 & a4 \\
\hline 194.7 & 575.63 & 2.71 & 20 & 18.5 & 0.15 & 0.025 & 2 \\
\hline
\end{tabular}

Rodrigues, H, Furtado, A, Arêde, A, Varum, $\mathrm{H}$ 


\subsubsection{Numerical model calibration}

The model calibration was performed by comparing the natural frequencies from the eigenvalue analysis with the results obtained from the ambient vibration tests. From the eigenvalue analysis, a natural frequency of $1.78 \mathrm{~Hz}$ (longitudinal direction of the structure) was obtained, which is equal to the experimental one provided by [21, 22]. The first three vibration modes of the structure and the corresponding frequencies are plotted in Figure 3.

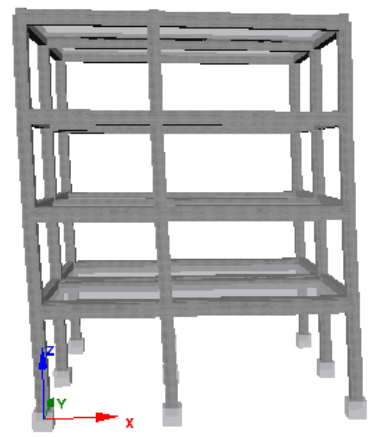

Mode: translational $X$ Numerical: $1.78 \mathrm{~Hz}$

Experimental: $1.78 \mathrm{~Hz}$

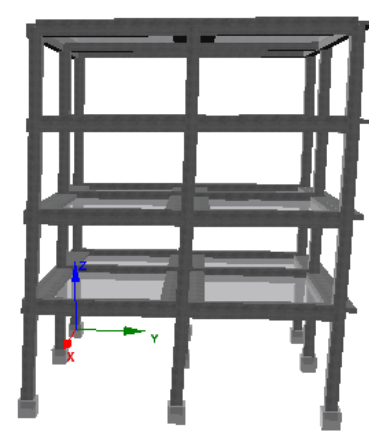

Mode: translational $Y$ Numerical: $1.85 \mathrm{~Hz}$

b)

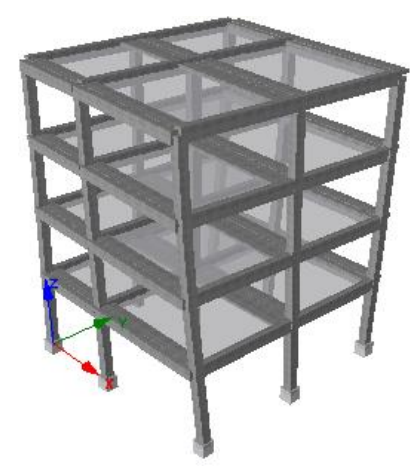

Mode: torsion Numerical: $1.99 \mathrm{~Hz}$

c)

Figure 3 Elsa frame structure: natural frequencies and vibration modes

The same calibration procedure was performed for the structures PT4 and PT6; however, in these cases, the numerical frequencies were compared with the analytical ones predicted by the designers and described in [23].

The eigenvalue analysis for both models is summarized in

Table 5. From the results, a good agreement between the numerical and experimental results is observed, in particular for the first vibration mode, which is typically translational in the structure's longitudinal X-direction.

Table 5 Case studies: eigenvalue analysis results

\begin{tabular}{cccc}
\hline Model & Mode 1 & Mode 2 & Mode 3 \\
Elsa Frame Structure & Translational X & Mode: translational Y & Mode: torsion \\
& Numerical: $1.78 \mathrm{~Hz}$ & Numerical: $1.85 \mathrm{~Hz}$ & Numerical: $1.99 \mathrm{~Hz}$ \\
& Experimental: $1.78 \mathrm{~Hz}$ & & \\
& Translational X & Translational Y & Torsion \\
PT4 & Numerical: $1.46 \mathrm{~Hz}$ & Numerical: $1.61 \mathrm{~Hz}$ & Numerical: $2.20 \mathrm{~Hz}$ \\
& Analytical: $1.45 \mathrm{~Hz}$ & Analytical: $1.52 \mathrm{~Hz}$ & \\
& Translational X & Translational Y & Torsion \\
PT6 & Numerical: $1.13 \mathrm{~Hz}$ & Numerical: $1.32 \mathrm{~Hz}$ & Numerical: $1.79 \mathrm{~Hz}$ \\
& Analytical: $1.15 \mathrm{~Hz}$ & Analytical: $1.29 \mathrm{~Hz}$ & \\
\hline
\end{tabular}

\section{NUMERICAL RESULTS}

\subsection{Introduction}

The experimental studies performed over the recent years emphasized that the effect of the combined horizontal and vertical loadings should not be neglected. A correct assessment of the RC columns capacity will allow the improvement of some design criteria proposed by the international codes, which will reduce or prevent suboptimal performances during earthquakes.

With this aim, the results of the nonlinear pushover will be presented and discussed throughout this section, focusing on the columns' axial load variability. From the analyses, the axial load variability of the columns was Rodrigues, $\mathrm{H}$, Furtado, A, Arêde, A, Varum, $\mathrm{H}$ 
assessed according to the plan and height position, and a possible deduction of the impact in the local and global response. From the static pushover analysis, the following parameters were studied: inter-story drift ratios, axial load variation, story shear, and capacity curves (for each curve, the yielding displacement was determined according to EC8 annex B [36].

To simplify the results' plots discussion and interpretation, all the members' results were analyzed for each structure. For all the cases, the nomenclature presented in Figure 4 was assumed, where each column was designated as "CXYZ," which means the $\mathrm{X}$-column disposition in the $\mathrm{X}$-direction of the structure; $\mathrm{Y}$-column disposition in the $Y$-direction of the structure; Z-column disposition in the Z-direction of the structure.

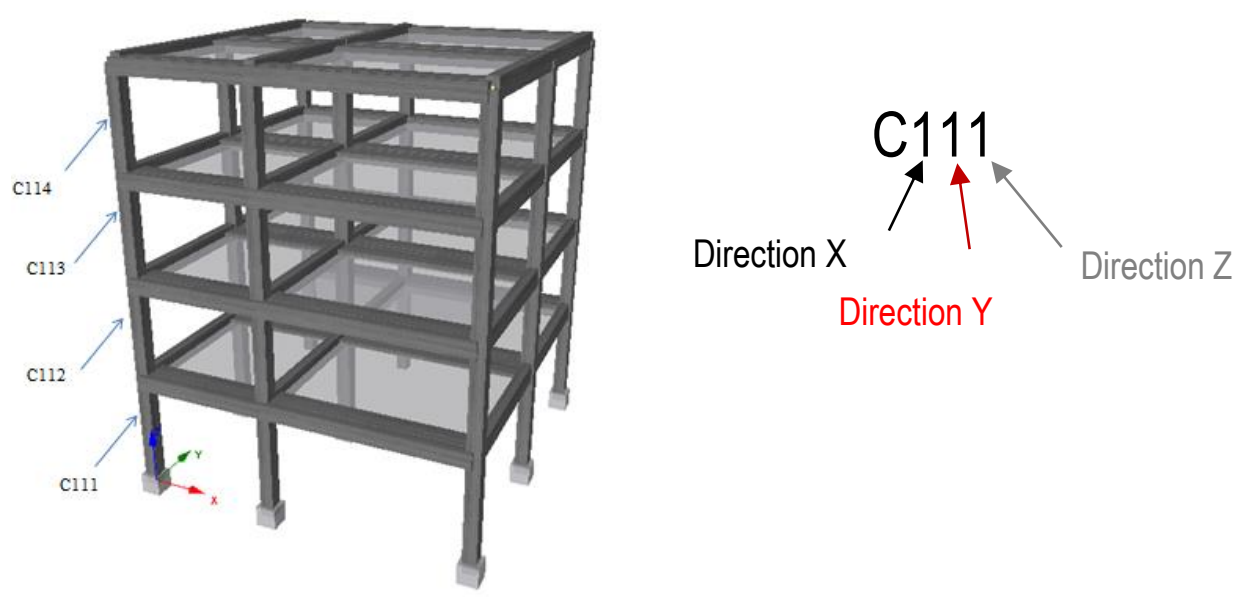

Figure 4 Assumed column nomenclature

\subsection{Elsa frame structure}

Figure 5 presents the axial load variation according to the inter-story drift ratio evolution for each story of three column types: corner, façade, and central columns that were obtained from the static pushover analyses. The curves for the yielding displacement determined from the top displacement vs. the story shear were also plotted. From the result analysis, it was verified that the maximum axial load relative variation occurred for inter-story displacements higher than the yielding ones determined for each story column under analysis. It was also found that after attaining the yielding displacement in each column section, the axial load's relative variation continues to increase, with higher variations in the corner columns and lower ones in the central columns. For a better understanding, the corner column (X-direction) plotted in Figure 5 a can be analyzed. For story levels $0-1$, the largest axial load relative variation occurred compared to the remaining levels. The lowest variation occurs in the story levels 2-3. Similar conclusions can be drawn for the façade and central columns, as shown in Figure $5 \mathrm{~b}$ and c, respectively.

From the result analysis of the transverse direction (Figure $5 d, e$, and f), the same conclusions can be drawn, in that the maximum axial load relative variation occurred for inter-story displacements higher than the corresponding yielding displacement, demonstrating that once the yield point has been reached on each column section, an increase in the relative variation of the axial load in the corresponding section of the abutment was still observed. The maximum axial load variation occurred in the bottom story levels $0-1$ and the lower one in the top story levels 2-3. 


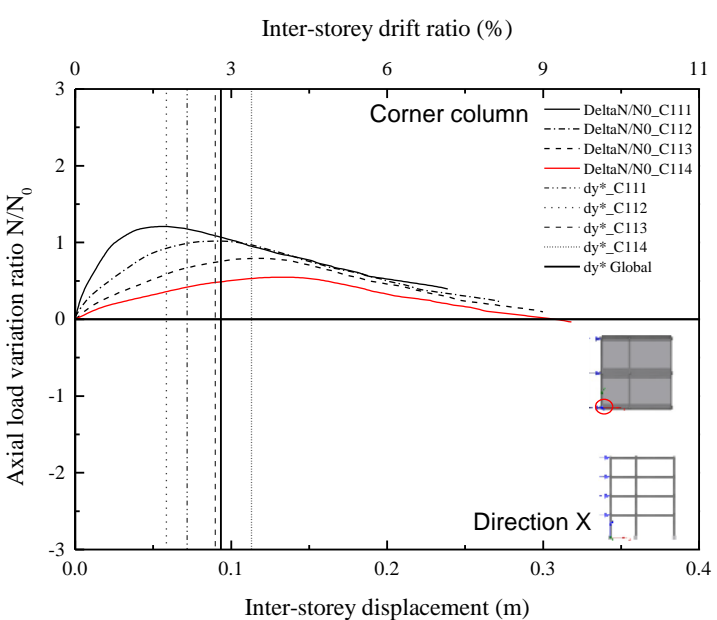

a)

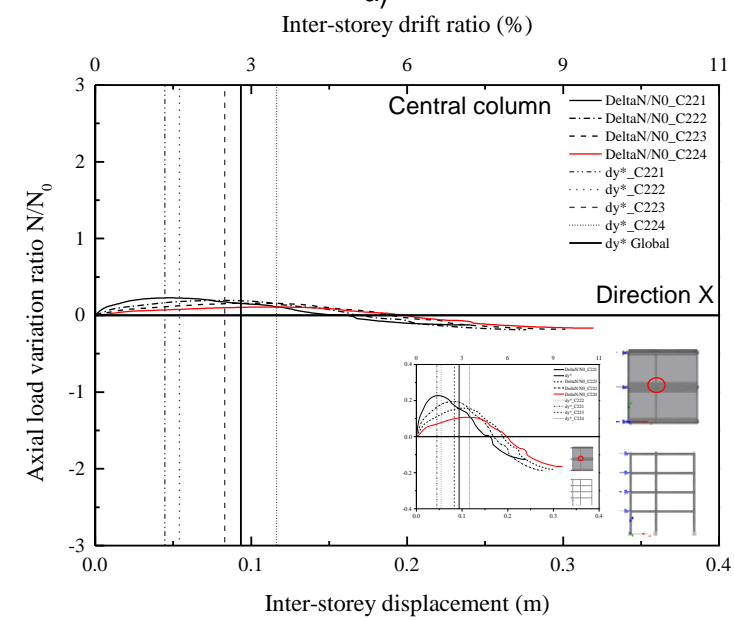

c)

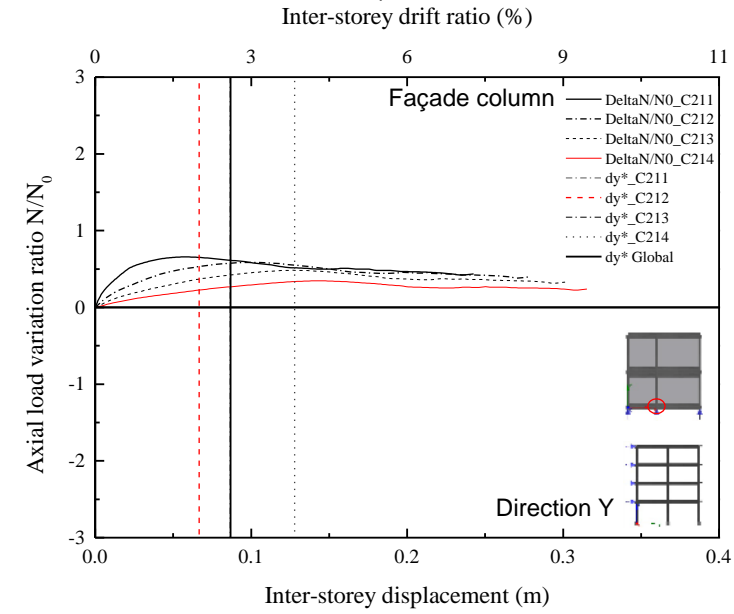

e)

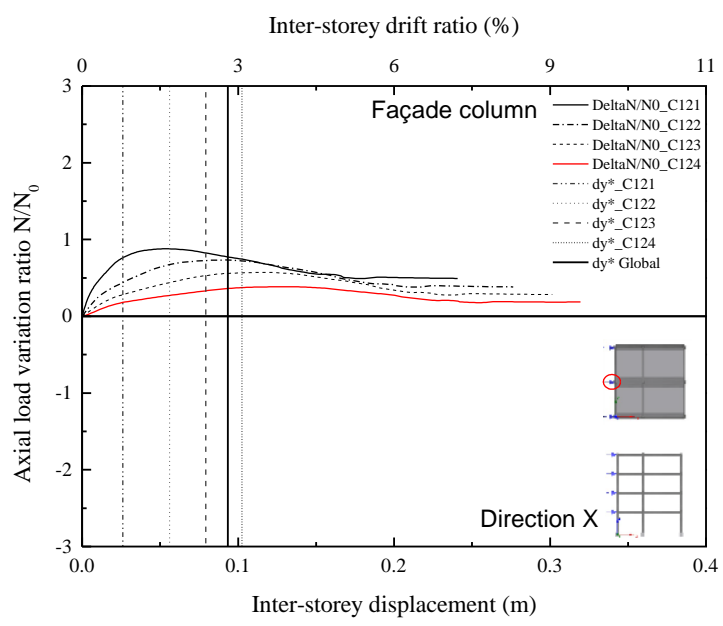

b)

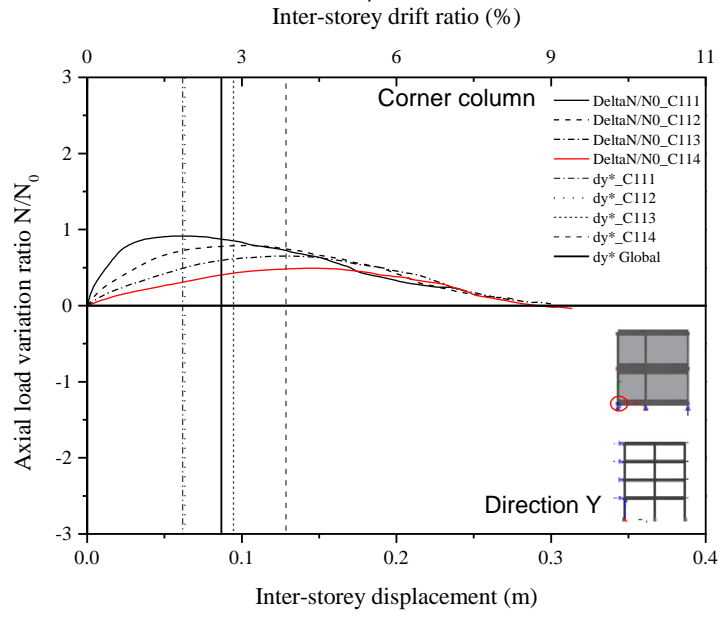

d)

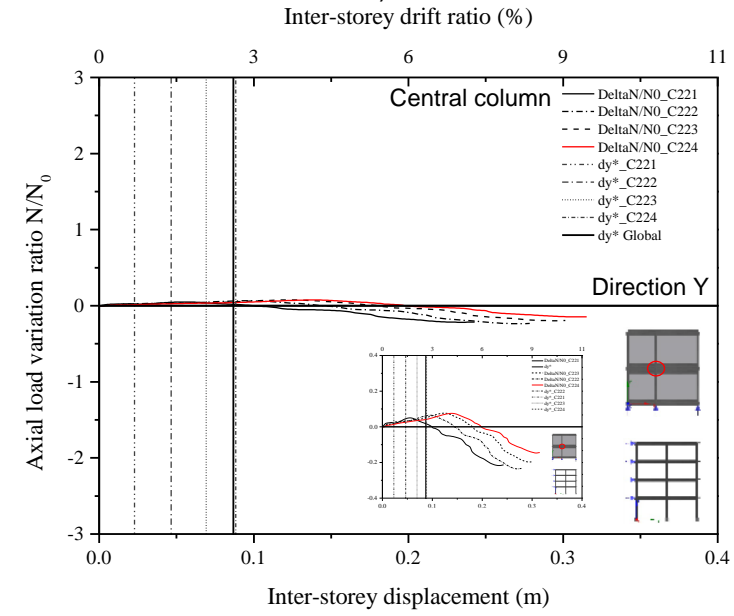

f)

Figure 5 Elsa frame results: axial load variation vs. inter-story drift ratio for each story level for $X$ direction a) corner column; b) façade column; central column; Y-direction d) corner column; e) façade column, and f) central column. 


\subsection{PT4 structure}

Through the analysis of the axial load variation in the PT4 structure (Figure 6), different axial load variations can be observed as they only occur until the inter-story displacements are near the yielding ones. This difference between the results of the first two storys is likely because the structure was designed according to the Portuguese structural design standards [24], where a direct design methodology was assumed, in which the nonlinear behavior was not the priority. Additionally, the code requires some assumptions similar to the capacity design concept for structures with high ductility, to ensure a better response in terms of strength, plastic deformation, and energy dissipation capacity. From the comparison between the axial load relative variations, it was noticed that the maximum variations occurred in the corner columns and the minimum ones in the central columns. Regarding the behavior along the structure height, it was observed that the axial load relative variation is higher in the bottom storys and decrease along the height. In addition to the variations along the structure height, some others can be found between the $X$ and $Y$ directions, which are related to some plan irregularities.

\subsection{PT6 structure}

Finally, the same static pushover analyses were applied to the structure PT6 (Figure 7), where it was verified that the higher maximum axial load relative variation occurred for interstory displacements higher than the yielding displacements of each column under analysis. Again, the maximum variation occurred in the corner columns, and the lower variation in the central ones.

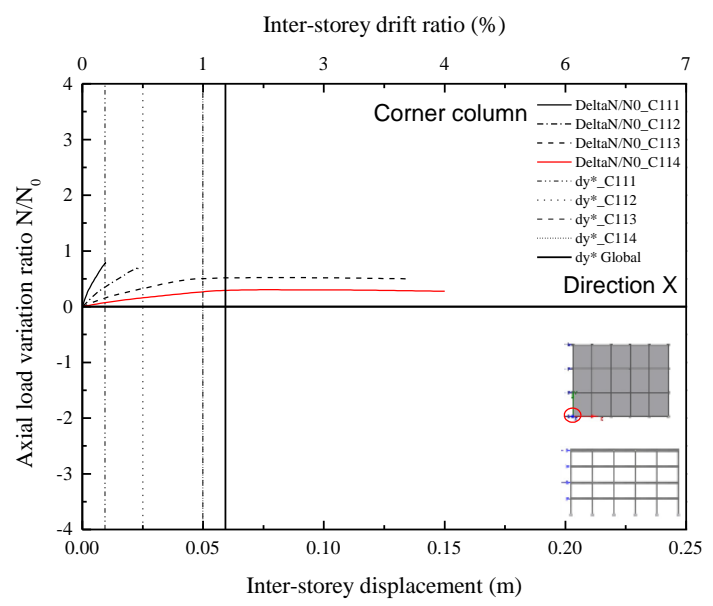

a)

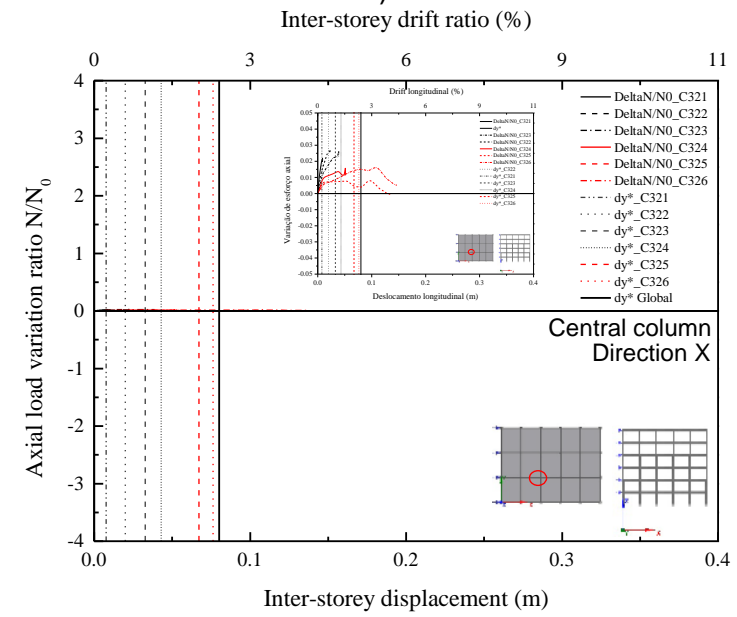

c)

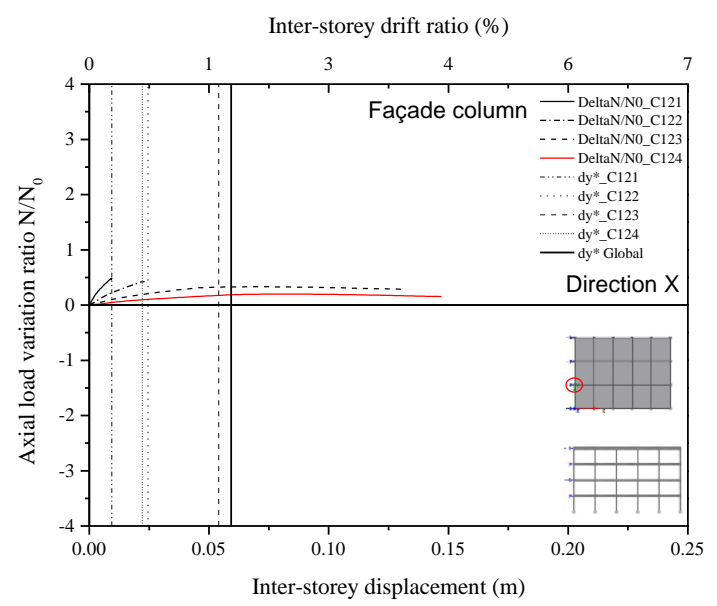

b)

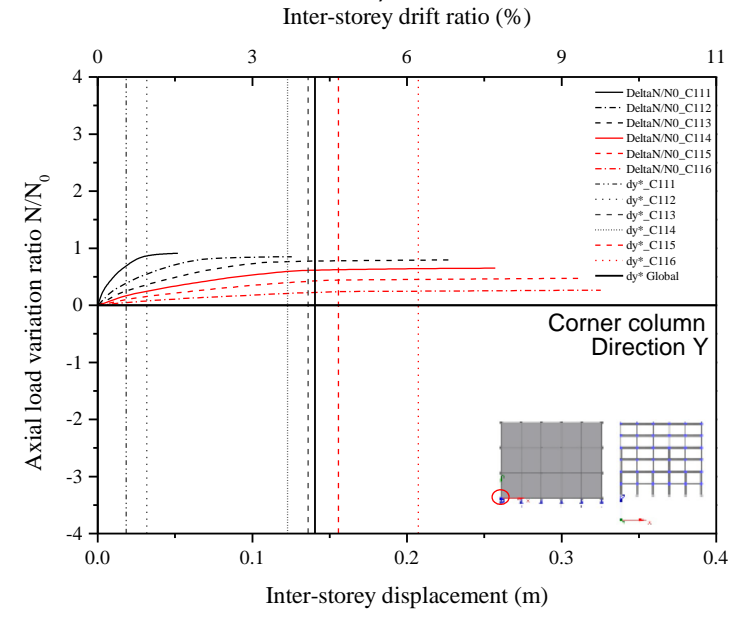

d)

Rodrigues, H, Furtado, A, Arêde, A, Varum, $\mathrm{H}$ 


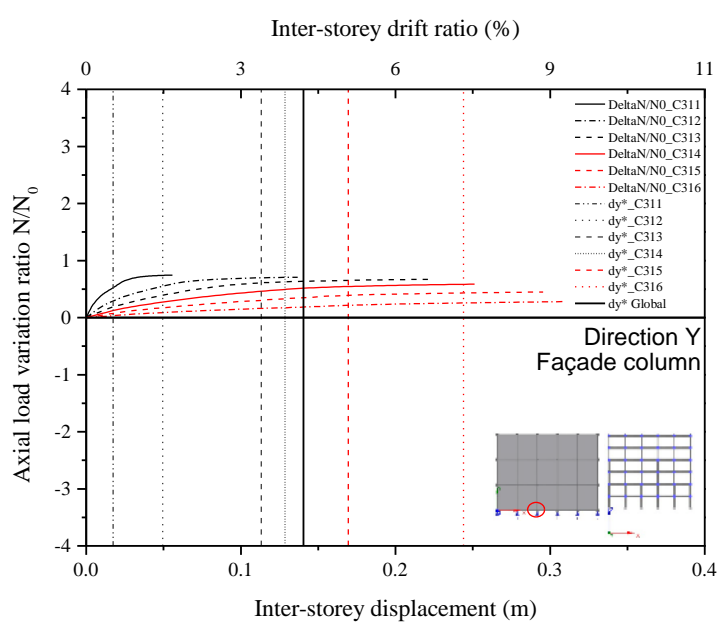

e)

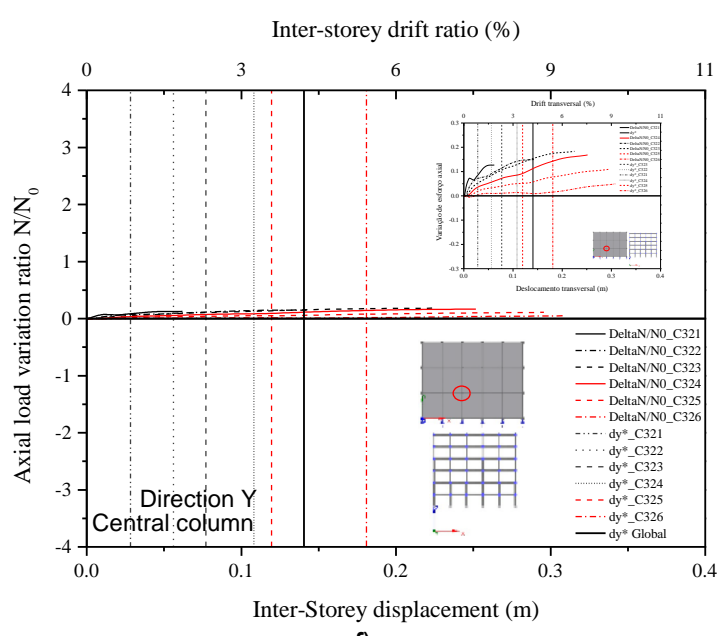

f)

Figure 6 PT4 results: axial load variation vs. inter-story drift ratio for each story level for X-direction a) corner column; b) façade column; central column; Y-direction d) corner column; e) façade column and f) central column

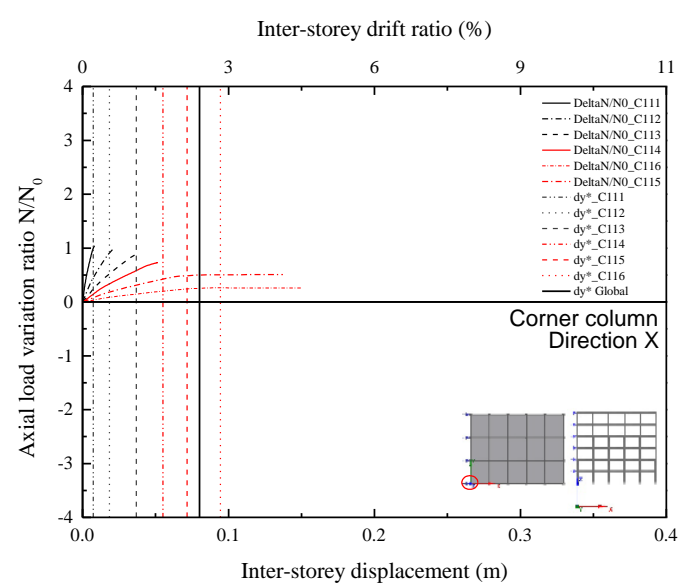

a)

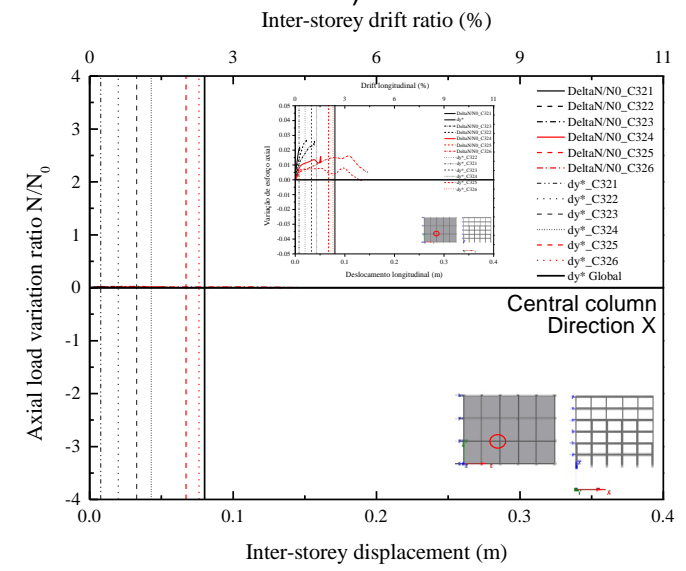

c)

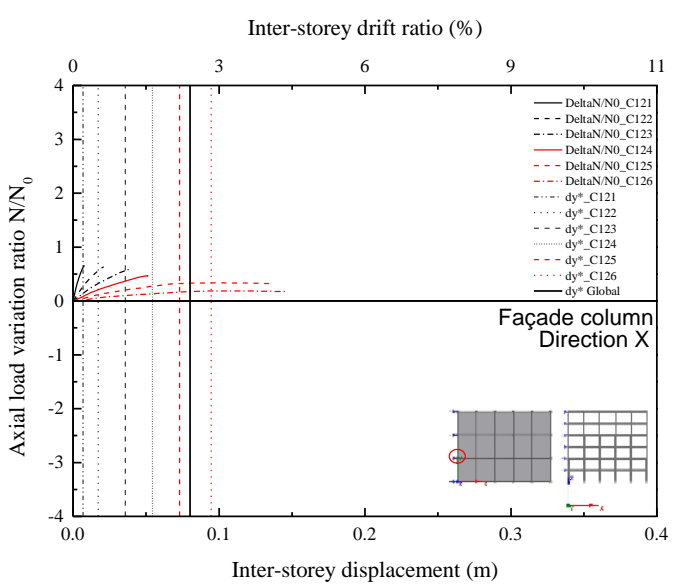

b)

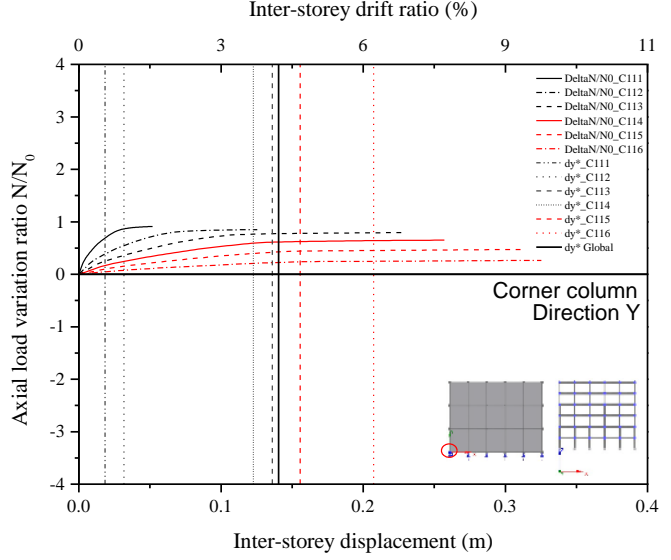

d)

Rodrigues, H, Furtado, A, Arêde, A, Varum, H 


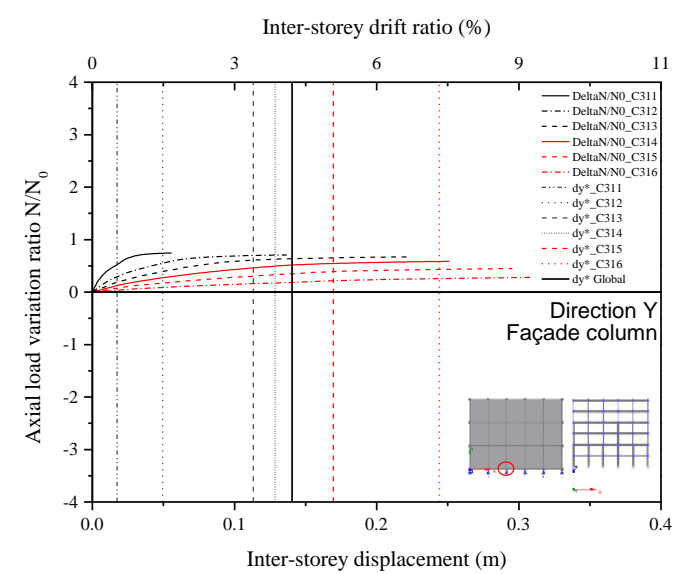

e)

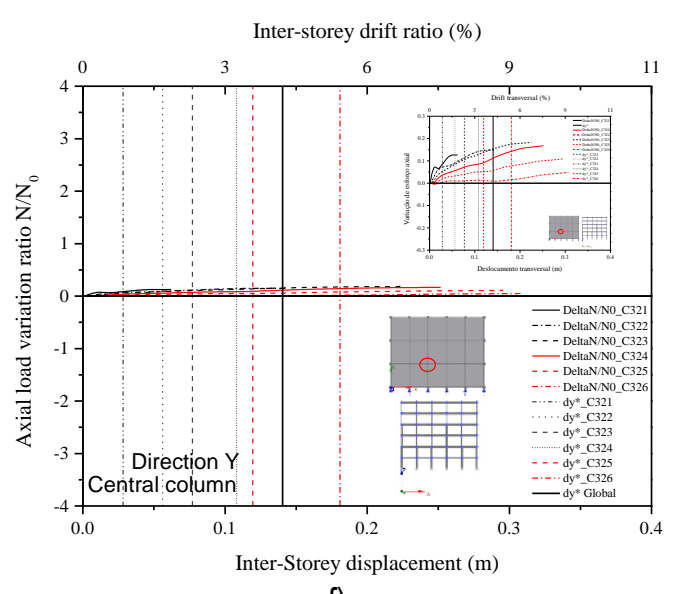

f)

Figure 7 PT6 results: axial load variation vs. inter-story drift ratio for each story level for X-direction a) corner column; b) façade column; central column; and Y-direction d) corner column; e) façade column and f) central column

\section{CONCLUSIONS}

The behavior of RC elements subjected to axial loading variation in conjunction with cyclic biaxial bending is recognized as a highly important research topic with few experimental results available.

The primary aim of this manuscript was to investigate the RC columns axial load relative variation according to the plan and height position, and subsequently assess the corresponding relationship between the biaxial flexure capacity and the influence in the global structural behavior. Hence, three structures with seismic design were studied using the software, SeismoStruct. Nonlinear static pushover analyses were performed in both directions of all three numerical models. From the study, it was concluded that the maximum axial load relative variations occurred at the structures' bottom storys, and that in all the case studies, the level of variation reduced along the height. The variation in the axial load was assessed for three column types: corner columns, façade columns, and central columns. From the analyses, it was observed that the higher variation occurred in the corner columns and the lowest variation in the central columns. As the variability in the columns' axial load reduces along the height, it was observed for the bottom columns that the inelastic behavior started for lower displacements in comparison with the remaining columns; subsequently, the strength capacity was reduced for lower displacement demands.

\section{ACKNOWLEDGMENTS}

The authors acknowledge the constructive comments and suggestions provided by the anonymous reviewers, which improved the manuscript quality.

\section{References}

[1] A. Masi, L. Chiauzzi, G. Santarsiero, V. Manfredi, S. Biondi, E. Spacone, et al., Seismic response of RC buildings during the Mw 6.0 August 24, 2016 Central Italy earthquake: the Amatrice case study, Bulletin of Earthquake Engineering, 2017/12/08 2017. https://doi.org/10.1007/s1051

[2] H. Varum, A. Furtado, H. Rodrigues, J. Dias-Oliveira, N. Vila-Pouca, and A. Arêde, Seismic performance of the infill masonry walls and ambient vibration tests after the Ghorka 2015, Nepal earthquake, Bulletin of Earthquake Engineering, vol. 15, pp. 1185-1212, March 01 2017. DOI 10.1007/s10518-016-9999-z

[3] R. Vicente, H. Rodrigues, H. Varum, A. Costa, and R. Mendes da Silva, Performance of masonry enclosure walls: lessons learned from recent earthquakes, Earthquake Engineering and Engineering Vibration, vol. 11, pp. 23-34, 2012. https://doi.org/10.1007/s11803-012-0095-3 
[4] X. Romão, A. A. Costa, E. Paupério, H. Rodrigues, R. Vicente, H. Varum, et al., Field observations and interpretation of the structural performance of constructions after the 11 May 2011 Lorca earthquake, Engineering Failure Analysis, vol. 34, pp. 670-692, 2013. https://doi.org/10.1016/i.engfailanal.2013.01.040

[5] J. Shayanfar and H. Akbarzadeh Bengar, Nonlinear analysis of RC frames considering shear behaviour of members under varying axial load, Bulletin of Earthquake Engineering, vol. 15, pp. 2055-2078, 2017/05/01 2017. DOI 10.1007/s10518-016-0060-z

[6] J. H. Kim and H. S. Lee, Reliability assessment of reinforced concrete rectangular columns subjected to biaxial bending using the load contour method, Engineering Structures, vol. 150, pp. 636-645, 2017/11/01/ 2017. DOI: 10.1016/j.engstruct.2017.07.061

[7] M. A. Özdemir, I. Kazaz, and S. G. Özkaya, Evaluation and comparison of ultimate deformation limits for RC columns, Engineering Structures, vol. 153, pp. 569-581, 2017/12/15/ 2017. DOI: 10.1016/j.engstruct.2017.10.050

[8] E. N. Farsangi and A. A. Tasnimi, The influence of coupled horizontal-vertical ground excitations on the collapse margins of modern RC-MRFs, International Journal of Advanced Structural Engineering (IJASE), vol. 8, pp. 169-192, 2016/06/01 2016. 10.1007/s40091-016-0122-0

[9] E. Farsangi, A. A. Tasnimi, and B. Mansouri, Fragility assessment of RC-MRFs under concurrent verticalhorizontal seismic action effects, computers and Concrete, vol. 6, pp. 99-123, 2015. DOI: 10.12989/cac.2015.16.1.099

[10] E. Farsangi, Y. T., and A. A. Tasnimi, Influence of concurrent horizontal and vertical ground excitations on the collapse margins of non-ductile RC frame buildings, Structural engineering and mechanics, vol. 59, pp. 653-669, 2016. DOI: 10.12989/sem.2016.59.4.653

[11] H. Rodrigues, A. Furtado, and A. Arêde, Behavior of Rectangular Reinforced-Concrete Columns under Biaxial Cyclic Loading and Variable Axial Loads, Journal of Structural Engineering, vol. 142, 2016. DOI: 10.1061/(ASCE)ST.1943-541X.0001345

[12] J. L. Bonet, M. H. F. M. Barros, and M. L. Romero, Comparative study of analytical and numerical algorithms for designing reinforced concrete sections under biaxial bending, Computers and Structures, vol. 84, pp. 2184-2193, 2006. DOI: 10.1016/j.compstruc.2006.08.065

[13] M. G. Sfakianakis and M. N. Fardis, RC Column model for inelastic seismic response analysis in 3D, Journal of Engineering Mechanics, vol. 117, pp. 2770-2787, 1991. DOI: 10.1061/(ASCE)07339399(1991)117:12(2770)

[14] H. Rodrigues, H. Varum, A. Arêde, and A. G. Costa, Behaviour of reinforced concrete column under biaxial cyclic loading - state of the art, International Journal of Advanced Structural Engineering, vol. 5, pp. 1-12, 2013. https://doi.org/10.1186/2008-6695-5-4

[15] K. N. Li, H. Aoyama, and S. Otani, Reinforced concrete columns under varying axial load and bidirectional horizontal load reversals, Proceedings of the 9th World Conference on Earthquake Engineering, 1998.

[16] S. Low and J. P. Moehle, Experimental study of reinforced concrete columns subject to multiaxial cyclic loading, Earthq. Engrg. Res. Center, vol. Rep. No UCB/EERC 87-14, Univ. of California, Berkeley, Ca., 1987. doi:10.1186/2008-6695-5-4

[17] H. Rodrigues, A. Arêde, A. Furtado, and P. Rocha, Seismic behavior of strengthened RC columns under biaxial loading: An experimental characterization, Construction and Building Materials, vol. 95, pp. 393-405, 2015. 10.1016/j.conbuildmat.2015.07.149

[18] H. Rodrigues, A. Arêde, A. Furtado, and P. Rocha, Seismic Rehabilitation of RC Columns Under Biaxial Loading: An Experimental Characterization, Structures, vol. 3, pp. 43-56, 2015. https://doi.org/10.1016/i.istruc.2015.03.001

[19] H. Rodrigues, A. Furtado, A. Arêde, N. Vila-Pouca, and H. Varum, Experimental study of repaired RC columns subjected to uniaxial and biaxial horizontal loading and variable axial load with longitudinal reinforcement welded steel bars solutions, Engineering Structures, vol. 155, pp. 371-386, 2018/01/15/ 2018. DOI: 10.1016/j.engstruct.2017.11.043

[20] G. Xu, B. Wu, D. Jia, X. Xu, and G. Yang, Quasi-static tests of RC columns under variable axial forces and rotations, Engineering Structures, vol. 162, pp. 60-71, 2018/05/01/ 2018. DOI: 10.1016/j.engstruct.2018.02.004 
[21] A. Arêde, Seismic assessment of reinforced concrete frame structures with a new flexibility based element., PhD Thesis, Faculdade de Engenharia, Universidade do Porto, Porto, 1997.

[22] E. Mola and P. Negro, Full-scale PSD testing of the torsionally unbalanced spear structure in the 'as-built' and retrofitted configurations, presented at the Proc. of SPEAR International Workshop, 2005.

[23] E. Carvalho and E. Coelho, Análise Sísmica de estruturas de edifícios segundo a nova regulamentação Análise Estrutural de um conjunto de 22 edifícios vol. II. Lisboa, Portugal, 1984.

[24] RSA, Regulamento de Segurança e Acções para Estruturas de Edifícios e Pontes, Decreto-Lei n. ${ }^{0}$ 235/83, de 31 de Maio, ed, 1983.

[25] Eurocode 2: Design of concrete structures - Part 1-1: General rules and rules for buildings, CEN, 2004.

[26] Seismosoft, SeismoStruct - a computer program for static and dynamic nonlinear analysis of framed structures [online], ed, 2004.

[27] M. J. N. Priestley and R. Park, Strength and Ductility of Concrete Bridge Columns Under Seismic Loading, ACI Structural Journal, vol. 84, pp. 61-76, 1987.

[28] T. Paulay and M. J. N. Priestley, Seismic design of RC and masonry buildings - John Wiley - ISBN 0-47154915-0, 1992.

[29] K. Tsuno and R. Park, Experimental study of reinforced concrete bridge piers subjected to bi-directional quasi-static loading, Struct. Engrg Structures, JSCE, vol. 21, No 1 11s-26s, 2004. https://doi.org/10.2208/jsceseee.21.11s

[30] H. Rodrigues, H. Varum, A. Arêde, and A. Costa, A comparative efficiency analysis of different non-linear modelling strategies to simulate the biaxial response of RC columns, Earthquake Engineering and Engineering Vibration, vol. 11, pp. 553-566, 2012.

[31] J.B. Mander, M.J.N. Priestley, and R. Park, Theoretical stress-strain model for confined concrete, Journal of Structural Engineering, vol. 114, pp. 1804-1826, 1988. DOl: 10.1061/(ASCE)0733-9445(1988)114:8(1804)

[32] P. Madas and A. S. Elnashai, A new passive confinement model for transient analysis of reinforced concrete structures, Earthquake Engineering and Structural Dynamics, vol. 21, pp. 409-431, 1992.

[33] J.E. Martinez-Rueda and A. S. Elnashai, Confined concrete model under cyclic load, Materials and Structures, vol. 30, pp. 139-147, 1997.

[34] M. Menegotto and P. E. Pinto, Method of analysis for cyclically loaded R.C. plane frames including changes in geometry and non-elastic behaviour of elements under combined normal force and bending, presented at the Symposium on the Resistance and Ultimate Deformability of Structures Acted on by Well Defined Repeated Loads, International Association for Bridge and Structural Engineering, Zurich, Switzerland, 1973.

[35] F. C. Filippou, E. P. Popov, and V. V. Bertero, Modelling of R/C joints under cyclic excitations, ASCE Journal of Structural Engineering, vol. 109, pp. 2666-2684, 1983. https://doi.org/10.1007/s41062-016-0008-9

[36] Eurocode 8: Design of structures for earthquake resistance - Part 1-1: General rules, seismic actions and rules for buildings, B. European Committee for Standardization, Belgium, 2003.

Please cite this article as:

Rodrigues, H, Furtado, A, Arêde, A, Varum, $\mathrm{H}$ : Influence of seismic loading on axial load variation in reinforced concrete columns, Electronic Journal of the Faculty of Civil Engineering Osijek-e-GFOS, 16, pp. 37-49, https://doi.org/10.13167/2018.16.4 